\title{
GAMBARAN PENGETAHUAN, SIKAP, DAN TINDAKAN MAHASISWA JURUSAN FARMASI POLTEKKES KEMENKES MEDAN TERHADAP PENCEGAHAN COVID-19
}

\author{
Ahmad Purnawarman Faisal ${ }^{1}$, Nurul Hidayah ${ }^{2}$, Adhisty Nurpermatasari ${ }^{3}$, Riza Fahlevi Wakidi ${ }^{4}$, Zulfa \\ Ismaniar Fauzi ${ }^{5}$, Pratiwi Rukmana Nasution ${ }^{6}$ \\ Poltekkes Kemenkes Medan ${ }^{123456}$ \\ e-mail: ${ }^{1}$ purn28@gmail.com, ${ }^{2}$ nurul.hidayah3607@gmail.com, ${ }^{3} d z$ buns@gmail.com, \\ rizafahlevi11@gmail.com, ${ }^{5}$ zismaniar76@gmail.com, ${ }^{6}$ apotekerpratiwinst@gmail.com
}

\begin{abstract}
Coronavirus 2019 or COVID-19 is a pandemic that has resulted in high mortality rates in various parts of the world. Good knowledge about the COVID-19 pandemic and clean and healthy living behavior as an effort to prevent the transmission of COVID-19 is important to implement. The purpose of this study was to describe the knowledge, attitudes, and actions about COVID-19 among students of the Department of Pharmacy, Poltekkes, Ministry of Health, Medan. This research method uses a descriptive survey with simple random sampling technique. The characteristics of the respondents, totaling 146 people, were obtained online with the criteria for male-female 111 people and male 34 people.

For the level of knowledge, the most answered statements for positive statements were statements Strongly Agree (SS) by 70.5\%, namely the statement "COVID-19 first emerged from China". Attitude level (SS) is 50\% in the statement "Knowing that the spread and transmission of COVID-19 can be through the air, you try to reduce activities outside the home", and Action, positive statement (SS) is $65.1 \%$ in the statement "Efforts can be made to break the chain of transmission of COVID-19 is by social distancing and implementing Health Protocols"

The conclusion of this study is that the level of knowledge, attitudes, and actions of students(i) towards COVID19 prevention, are $84,23 \%(\mathrm{good}), 85.53 \%(\mathrm{good})$, and $83.64 . \%(\mathrm{good})$.
\end{abstract}

Keywords: Knowledge; Attitude; Action; Covid-19

\begin{abstract}
ABSTRAK
Coronavirus 2019 atau COVID-19 merupakan pandemi yang telah mengakibatkan tingginya angka mortalitas di berbagai belahan dunia. Pengetahuan mengenai pandemic COVID-19 yang baik dan perilaku hidup bersih dan sehat sebagai upaya mencegah penularan COVID-19 penting untuk diterapkan. Tujuan penelitian ini untuk mengetahui gambaran pengetahuan, sikap, dan Tindakan tentang COVID-19 pada Mahasiswa Jurusan Farmasi Poltekkes Kemenkes Medan. Metode penelitian ini menggunakan survey deskriptif dengan Teknik simple random sampling. Karateristik responden yang berjumlah 146 orang diperoleh secara daring dengan klriteria laki-perempuan 111 orang dan laki-laki 34 orang.

Untuk tingkat pengetahuan, pernyataan yang paling banyak dijawab untuk pernyataan positif adalah pernyataan Sangat Setuju (SS) sebesar 70,5\% yaitu pernyataan "COVID-19 pertama kali muncul dari Negara China". Tingkat Sikap (SS) sebesar 50\% pada pernyataan "Mengetahui penyebaran dan penularan COVID-19 bisa melalui udara, anda mencoba mengurangi aktivitas diluar rumah", dan Tindakan, pernyataan positif (SS) sebesar $65,1 \%$ pada pernyataan "Upaya yang dapat dilakukan untuk memutus rantai penularan COVID-19 adalah dengan Social distancing dan menerapkan Protokol Kesehatan"

Kesimpulan dari penelitian ini adalah tingkat pengetahuan, sikap, dan tindakan pencegahan COVID-19 berturut-turut adalah 84,23\% (baik), 85,53\% (baik), dan 83,64\% (baik).
\end{abstract}

Kata kunci: Pengetahuan; Sikap; Tindakan; Covid-19 


\section{PENDAHULUAN}

Kesehatan (UU NO. 36 Tahun 2009) adalah keadaan sehat, baik secara fisik, mental, spiritual maupun sosial yang memungkinkan setiap orang untuk hidup produktif secara sosial dan ekonomis. Setiap orang berhak atas kesehatan. Kesehatan merupakan hak asasi manusia dan salah satu unsur kesejahteraan yang harus diwujudkan sesuai dengan cita-cita bangsa Indonesia sebagaimana dimaksud dalam Pancasila dan UndangUndang Dasar Negara Republik Indonesia Tahun 1945.

WHO (World Health Organization) menyatakan pandemi COVID-19 sebagai keadaan darurat kesehatan masyarakat internasional ${ }^{4)}$. Dari data Gugus Tugas COVID-19 Republik Indonesia, per tanggal 3 Agustus 2021 total pasien positif COVID-19 sebesar 3.496.700 orang, dengan pasien sembuh sebesar 2.873.669 orang dan pasien meninggal sebear 98.889 orang. Berdasarkan data Gugus Tugas COVID-19 Republik Indonesia, per tanggal 3 Agustus 2021 di Medan mencapai 29.955 kasus konfirmasi, 21.401 sembuh, dan 690 orang meninggal.

Kasus COVID-19 yang meningkat terjadi pada masyarakat dikarenakan virus yang tersebar dengan cepat, baik dari hewan ke manusia ataupun antara manusia. Penularan virus SARS-CoV-2 dari hewan ke manusia utamanya disebabkan oleh konsumsi hewan yang terinfeksi virus tersebut sebagai sumber makanan manusia, seperti hewan keleawar. Begitupun pada manusia, kontak yang erat dengan pasien terinfeksi COVID-19 akan mempermudah proses penularan COVID-19 antara manusia. Penularan COVID-19 terjadi karena keluarnya droplet manusia yang mengandung virus SARS-CoV-2 ke udara oleh pasien terinfeksi pada saat batuk ataupun bersin. Droplet di udara selanjutnya dapat terhirup oleh manusia lain di dekatnya yang tidak terinfeksi COVID-19 melalui hidung ataupun mulut. Droplet tersebut lalu masuk menembus paru-paru dan infeksi pada manusia yang sehat berlanjut ${ }^{4)}$. Sehingga ini akan menyebabkan peningkatan ancaman pandemi COVID-19 dan jumlah meningkatnya kasus COVID-19 di masyarakat.

Perlu adanya Tindakan preventif untuk mengurangi dampak pandemi ini dengan Perlikau Hidup Bersih dan Sehat. Untuk mencapainya, seperti terapan protokol Kesehatan, yaitu mencuci tangan dengan sabun, penggunaan masker, menjauhi kerumunan, menjaga jarak, dan membatasi mobilisasi dan interaksi. Sehingga dengan adanya protokol ini, maka perlunya penelitian untuk mengetahui gambaran pengetahuan masyarakat tentang pandemi COVID-19 dan perilaku Mahasiswa di masa pandemi COVID-19, khususnya pada Mahasiswa Jurusan Farmasi Poltekkes Kemenkes Medan.

\section{METODE}

Penelitian ini hanya menggambarkan objek yang diteliti yaitu Pengetahuan, Sikap, dan Tindakan Mahasiswa tentang COVID-19 di Jurusan Farmasi Poltekkes Kemenkes Medan.

\section{Jenis Penelitian}

Jenis penelitian yang digunakan adalah penelitian survey dengan desain deskriptif.

\section{Lokasi dan Waktu Penelitian}

Penelitian ini berlokasi di Jurusan Farmasi Poltekkes Kemenkes Medan

\section{Populasi dan Sampel}

Populasi dalam penelitian ini adalah seluruh Mahasiswa(i) Jurusan Farmasi Poltekkes Kemenkes Medan berjumlah 356 orang

\section{Pengumpulan Data}

Data yang digunakan meliputi data primer dan sekunder. Data primer menggunakan kuisioner yang berisi pernyataan dan pertanyaan dengan skala likert. Data sekunder diperoleh dari pihak Akademik Jurusan Farmasi Poltekkes Kemenkes Medan.

\section{Pengolahan dan Analisis Data}

Kategori Pengetahuan, Sikap dan Tindakan diukur berdasarkan Skala Likert yang mempertimbangkan pendapat dan persepsi seseorang atau kelompok orang tentang fenomena sosial ${ }^{9}$.

\section{HASIL}

\section{Karateristik Responden}

Karateristik responden yang berjumlah 146 orang diperoleh secara daring, melalui link google form.

Tabel 1. Tabel distribusi Karateristik Responden

\begin{tabular}{lll}
\hline $\begin{array}{l}\text { Karateristik } \\
\text { Responden }\end{array}$ & $\begin{array}{l}\text { Frekuensi } \\
\text { (orang) }\end{array}$ & $\begin{array}{l}\text { Presentasi } \\
(\%)\end{array}$ \\
\hline $\begin{array}{l}\text { Jenis Kelamin } \\
\text { Perempuan }\end{array}$ & 112 & 76,71 \\
Laki-laki & 34 & 23,29 \\
\hline
\end{tabular}

\section{Gambaran Pengetahuan, Sikap, dan Tindakan Responden}

Jurusan Farmasi Poltekkes Kemenkes Medan terletak di Jl. Airlangga No. 20 Medan. Kampus ini terakreditasi B. dengan jumlah keseluruhan mahasiswa sebanyak 356 orang. Dalam Penyebaran kuisioner melalui link, sebanyak 146 orang yang berpartisipasi dalam pengisian.

Tabel 2. Tabel Distribusi Frekuensi Tingkat Pengetahuan, Sikap, dan Tindakan Responden

Pengetahuan 


\begin{tabular}{lcccccc} 
Parameter & SS & S & RR & TS & STS & al \\
\hline Pengetah & 48.7 & 33.7 & 10.2 & 4.6 & 2.6 & \\
uan & 3 & 0 & 1 & 9 & 7 & 100 \\
\hline Sikap & 45.0 & 40.6 & 11.2 & 2.7 & 0.4 & \\
\hline & 7 & 8 & 3 & 4 & 1 & 100 \\
Tindakan & 43.2 & 39.6 & 10.5 & 5.0 & 1.5 & \\
\hline
\end{tabular}

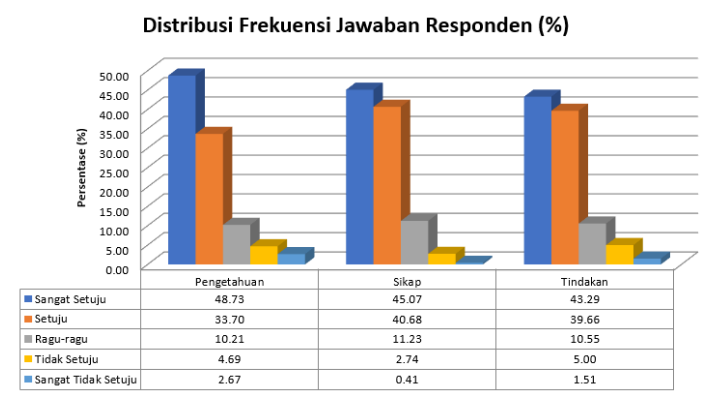

Gambar 1. Distribusi Frekuensi Jawaban Responden

Tabel 3. Rata-rata parameter dari beberapa kategori

\begin{tabular}{ccl}
\hline Parameter & $\begin{array}{c}\text { Rata- } \\
\text { Rata }\end{array}$ & \multicolumn{1}{c}{ Kategori } \\
\hline Pengetahuan & 84.23 & $\begin{array}{l}\text { Sangat } \\
\text { Baik/Baik }\end{array}$ \\
\hline Sikap & 85.53 & $\begin{array}{l}\text { Sangat } \\
\text { Baik/Baik }\end{array}$ \\
\hline Tindakan & 83.64 & $\begin{array}{l}\text { Sangat } \\
\text { Baik/Baik }\end{array}$ \\
\hline
\end{tabular}

\section{PEMBAHASAN}

\section{Pengetahuan}

Domain kognitif pada pengetahuan memiliki 6 tingkatan yaitu tahu, memahami, aplikasi, analisis, sintesis, dan evaluasi. (Notoadmojo, 2003).

Dari tabel 2 terlihat pernyataan yang paling banyak dijawab untuk pernyataan positif adalah pernyataan Sangat Setuju (SS) sebesar 70,5\% yaitu pernyataan "COVID-19 pertama kali muncul dari Negara China", Pernyataan Setuju (SS) 43,2\% pada 2 pernyataan "Gejala yang dapat ditimbulkan terhadap pasien yang terserang COVID-19 adalah demam dan batuk" dan "Yang lebih rentan terinfeksi COVID-19 adalah orang yang lebih tua daripada orang yang lebih muda", pernyataan Ragu-ragu (R) $28 \%$ pada pernyataan "Jika anda pulih dari COVID-19, anda akan kebal terkena infeksi lagi".

Uniknya, Pernyataan negatif seperti pernyataan Tidak Setuju (TS) dan (Sangat Tidak Setuju (STS) dengan besaran masing-masing $24,7 \%$ dan $16,4 \%$ pada pernyataan yang sama "Jika anda pulih dari COVID19, anda akan kebal terkena infeksi lagi".

Jumlah skor seluruh pengetahuan responden adalah 1423. Secara keseluruhan tingkat pengetahuan responden tentang pencegahan Covid-19 pada mahasiswa(i) adalah $=(12297 / 14600) \times 100 \%=$ $84,23 \%$ termasuk dalam kategori baik.

Hal ini sesuai dengan pendidikan responden yang sudah masuk dalam pendidikan bertaraf perguruan tinggi ini rasa ingin tahu responden yang tinggi sehingga responden memanfaatkan sumber informasi seperti televisi, internet, telepon seluler untuk menambah tingkat pengetahuan mereka tentang Covid19.

\section{Sikap}

Tiga komponen pokok pada kategori Sikap ini6), menjelaskan bahwa sikap itu mempunyai tiga komponen yaitu pertama kepercayan, ide dan konsep terhadap suatu objek kedua yaitu kehidupan emosional atau evaluasi terhadap suatu objek, ketiga yaitu kecenderungan untuk bertindak.

Sikap responden pada penelitian ini meliputi sikap responden tentang pencegahan COVID-19. Dari tabel 2, menunjukkan bahwa pernyataan yang paling banyak dijawab untuk pernyataan positif adalah Sangat Setuju (SS) sebesar 50\% pada pernyataan "Mengetahui penyebaran dan penularan COVID-19 bisa melalui udara, anda mencoba mengurangi aktivitas diluar rumah", Pernyataan Setuju (S) sebesar 47,9\% pada pernyataan "Seluruh masyarakat harus melakukan Rapid test atau Swab test untuk meminimalisir terhadap penularan COVID-19", Pernyataan Raguragu $(\mathrm{R})$ sebesar $18,5 \%$ pada Pernyataan "Anda sangat mendukung semua program pemerintah terhadap penanganan COVID-19",

Sedangkan untuk pernyataan negatif, Pernyataan Tidak Setuju (TS) sebesar $4,1 \%$ pada 2 pernyataan yaitu "Apakah Anda setuju terhadap pembatasan aktivitas yang diterapkan dalam mencegah COVID-19" dan "Seluruh masyarakat harus melakukan Rapid test atau Swab test untuk meminimalisir terhadap penularan COVID-19" dan Pernyataan Sangat Tidak Setuju (STS) sebesar $0,7 \%$ pada semua pernyataan.

Jumlah skor seluruh sikap responden adalah 329. Secara keseluruhan tingkat pengetahuan responden tentang pencegahan Covid-19 pada mahasiswa(i) adalah $=(3122 / 3650) \times 100 \%=85,53 \%$ termasuk dalam kategori baik.

Menurut Azwar ${ }^{3)}$ beberapa faktor yang mempengaruhi sikap antara lain Pengalaman pribadi; Pengaruh orang lain yang dianggap penting; Pengaruh kebudayaan; Media massa; Lembaga penelitian dan lembaga pendidikan agama; dan Faktor emosional

Dari beberapa faktor sikap yang dikemukakan Azwar, ada 3 faktor yang mempengaruhi sikap baik dari responden ini yaitu dipengaruhi oleh pengalaman pribadi, media massa dan lembaga pendidikan. Pengalaman responden sangat berkaitan dengan pengetahuan yang mereka peroleh. Sementara itu pengetahuan diperoleh melalui kegiatan penyuluhan media massa seperti televisi, Koran, radio, dan alat komunikasi lainnya yang menyediakan informasiinformasi kesehatan. Lembaga pendidikan juga berkaitan dengan pengalaman pribadi responden. 
Melalui lembaga pendidikan responden dapat mengetahui virus COVID-19. Dari sikap responden ini maka dapat menimbulkan tindakan yang baik pula sehingga mahasiswa(i) dapat mencegah penyebaran virus Covid-19.

\section{Tindakan}

Tindakan mahasiswa(i) pada penelitian ini meliputi tindakan mahasiswa(i) tentang pencegahan COVID-19.

Pada Tabel 2, untuk Tindakan positif ditandai dengan pernyataan Sangat Setuju (SS) sebesar 65,1\% pada pernyataan "Upaya yang dapat dilakukan untuk memutus rantai penularan COVID-19 adalah dengan Social distancing dan menerapkan Protokol Kesehatan", pernyataan Setuju (S) sebesar 47,3\% pada pernyataan "Penanganan dan pencegahan yang diselenggarakan oleh pemerintah sudah sangat efektif", dan Ragu-ragu (R) sebesar $21,9 \%$ pada 2 pernyataan yaitu "Suplemen Vitamin $\mathrm{C}$ akan sepenuhnya dapat menangkal COVID-19" dan "Pemindai termal (suhu badan), yang digunakan untuk mengukur suhu tubuh seseorang dapat secara efektif mendiagnosis COVID19 ".

Sedangkan pada pernyataan negatif yaitu Tidak Setuju (T) dan Sangat Tidak Setuju (STS) ditujukan pada pernyataan "Pemindai termal (suhu badan), yang digunakan untuk mengukur suhu tubuh seseorang dapat secara efektif mendiagnosis COVID-19"

Jumlah skor seluruh tindakan responden adalah 632. Secara keseluruhan tingkat pengetahuan responden tentang pencegahan Covid-19 pada mahasiswa(i) adalah $=(6106 / 7300) \times 100 \%=83,64 \%$ termasuk dalam kategori baik.

Perilaku merupakan respon atau reaksi seseorang terhadap stimulus atau rangsangan dari luar6). Sikap juga dapat dicerminkan dalam suatu bentuk tindakan, namun bisa juga dikatakan bahwa sikap dan tindakan memiliki hubungan yang sistematis. Tindakan yang sangat baik terhadap pencegahan Covid-19 pada mahasiswa(i) Jurusan Farmasi Poltekkes Kemenkes Medan dikarenakan adanya kesadaran untuk menjaga jarak satu sama lain menerapkan hidup bersih dan sehat tidak lupa memakai masker saat keluar rumah dan selalu mencuci tangan di air mengalir.

\section{KESIMPULAN}

Tingkat pengetahuan, sikap, dan tindakan Mahasiswa(i) Jurusan Farmasi Poltekkes Kemenkes Medan terhadap Pencegahan COVID-19 berturut-turut adalah $84,23 \%$ (baik), 85,53\% (baik), dan $83,64 \%$ (baik).

Perlunya untuk lebih meningkatkan kembali Pengetahuan, Sikap, dan Tindakan khususnya tentang Kesehatan dalam pencegahan COVID-19 dalam bentuk kegiatan sosialisasi. Selain itu, diperlukan wawancara lebih mendalam terhadap mahasiswa(i) sehingga informasi yang tersedia lebih bervariasi.

\section{DAFTAR PUSTAKA}

1. A. Wawan dan Dewi, 2010, Teori dan Pengukuran Pengetahuan, Sikap dan Perilaku Manusia, Yogyakarta : Nuha Medika

2. Aspuah. 2013. Kumpulan Kuesioner Dan Instrumen Penelitian Kesehatan. Yogyakarta : Nuha Medika

3. Azwar S. 2013. Sikap Manusia: Teori dan Pengukurannya. Yogyakarta: Pustaka Pelajar.

4. Güner, R., Hasanoğlu, İ., \& Aktaş, F. (2020). Covid-19: Prevention and control measures in community. TurkishJournal of Medical Sciences, 50(SI-1), 571-577

5. Notoatmodjo, Soekidjo, 2003, Pengembangan Sumber Daya Manusia, Jakarta:PT. Rineka Cipta.

6. Notoatmodjo. 2012. Metode Penelitian Kesehatan. Jakarta : Rineka Cipta

7. covid19.go.id. (2020, 24 September). Satgas COVID-19 Tekankan Perilaku Disiplin Protokol Kesehatan Langkah Utama Atasi Pandemi. Diakses pada 2 Juni 2021, dari https://covid19.go.id/p/berita/satgas-covid-19tekankan-perilaku-disiplin-protokol-kesehatanlangkah-utama-atasi-pandem

8. Shereen, M. A., Khan, S., Kazmi, A., Bashir, N., \& Siddique, R. (2020). COVID-19 infection: Origin, transmission, and characteristics of human coronaviruses. Journal of Advanced Research, 24(1), 91-98.

9. Sugiyono. (2017). Metode Penelitian Kuantitatif, Kualitatif, dan R\&D. Bandung : Alfabeta, CV. 